\title{
98. Fission-track Dating Data on Fresh-water Sediments for the Study of Land Connection between the Asiatic Continent and Lake Biwa through the Seto Inland Sea
}

\author{
By Shoji HoRIE \\ Institute of Paleolimnology and Paleoenvironment \\ on Lake Biwa, Kyoto University \\ (Communicated by Teiichi Kobayashi, M. J. A., Dec. 12, 1986)
}

When our geologists look over the geological structure in the Japanese Archipelago, the most distinct feature they observe is the existence of the Median Dislocation line. Along that dislocation line, an inland sea named the Seto Inland Sea stretches from the east to the west and the area located in the north of that line is named the Inner Zone in contrast to the Outer Zone facing the Pacific Ocean in the south of the dislocation line. Kobayashi (1941) stressed the importance of Sakawa orogenic movements in a geological study of the Japanese Archipelago but he pointed out that neither the Senonian sea indicated by the Izumi sandstone nor the early Miocene sea flooded over the Chügoku region, they are not the progenitor of the Seto Inland Sea. Its history started with the downwarping after the middle Neogene peneplanation of the Kibi plateau. The primary inland sea opened its mouth in Central Kyūshū, but later it was dammed up by the eruption of Aso and other volcanoes. Finally the Pacific Sea ingreesed there through channels crossing the Outer Zone.

Apart from the geologic work for the orogenic movements, the author is going to discuss the first chronological clue for Late Cenozoic history of that district on the basis of fission-track dating on fresh-water sediments in connection with Lake Biwa history. A remarkable feature of the Late-Cenozoic is the formation of a peneplain - the Chūgoku Peneplain which is a very clearly denoted flat surface and monadnocks in the north of the Seto Inland Sea. According to Tsujimura (1952), that peneplain was formed after the orogenic movement of the Miocene Epoch. Although its flat morphological feature is not as distinct as that of the Chügoku Peneplain, the extension of a similar flat surface is found also in the mountains of Shikoku, Kii and Tamba-Mino (Lake Biwa is located inside it). Otuka (1952) interpreted this distribution of peneplain remnants as implying that the upwarping of that area caused an uplift to mountains on which even fragmentary surface is still left despite the erosion and weathering. In his opinion, the Seto Inland Sea is an area that has to subside (downwarping in the axis from the east to the west in the author's opinion). If so, it is possible that the basement rock underneath the present inland sea deposits is a downwarped peneplain. Then, the focus of the author's discussion is to be the transition of the Seto Inland Sea since the Miocene Epoch.

On the other hand, the western limit of the Seto Inland Sea is demarcated by the Kyūshū Islands and just on the extension zone of the Seto Inland Sea, there is a huge caldera of the Aso Volcano which is still active at the present time. If the Aso Volcano had not erupted, the Seto Inland Sea may have stretched westwards into the East China Sea. 
Table I. Fission-track dating data*

\begin{tabular}{|c|c|c|}
\hline Stratigraphy & Locality & Age \\
\hline \multicolumn{2}{|l|}{ Ōita Group (Ōita Prefecture) } & (Million years) \\
\hline Shimogōri Alternation & Akeno, Ōita City & $0.60 \pm 0.23 \mathrm{Ma}$ \\
\hline Hada Pyroclastic Flow & Hada, Ōita City & $0.68 \pm 0.18$ \\
\hline Kodōbaru Tuff & Kojōyama, Ōita City & $1.1 \pm 0.3$ \\
\hline Shikido Pumice Fall & Shikiko, Ōita City & $1.3 \pm 0.3$ \\
\hline \multicolumn{3}{|l|}{ (Upper) } \\
\hline Handa Formation & Katano, Öita City & $2.2 \pm 0.8$ \\
\hline Handa Formation & Shimotakae, Ōita City & $2.4 \pm 0.8$ \\
\hline $\begin{array}{c}\text { Mitsuyoshi Alternation } \\
\text { (Lower) }\end{array}$ & Shimooshino, Ōita City & $2.7 \pm 0.5$ \\
\hline Handa Formation & Itayama, Öita City & $2.9 \pm 0.6$ \\
\hline \multicolumn{3}{|c|}{ Yame Group (Fukuoka Prefecture) } \\
\hline Kurume Formation (Lower) & Kōzuka, Kurume City & $2.7 \pm 0.2$ \\
\hline Kuroki Formation & $\begin{array}{l}\text { Uchikoshi, Jōyō-machi, } \\
\text { Yame-gun }\end{array}$ & $3.3 \pm 0.2$ \\
\hline Kuroki Formation & $\begin{array}{l}\text { Kaminakabaru, Jōyō-machi, } \\
\text { Yame-gun }\end{array}$ & $3.4 \pm 0.3$ \\
\hline \multicolumn{3}{|c|}{$\begin{array}{l}\text { Kuchinotsu Group (Nagasaki Prefecture) } \\
\text { Shimabara }\end{array}$} \\
\hline Ōya Formation (Upper) & Hirayama, Kitaarima-machi & $2.0 \pm 0.3$ \\
\hline Oya Formation (Upper) & Deguchi, Kitaarima-machi & $2.0 \pm 0.4$ \\
\hline Oya Formation (Lower) & Fujiyama, Kuchinotsu-machi & $2.6 \pm 0.5$ \\
\hline Oya Formation (Lower) & Mukaigoya, Minamiarima-machi & $4.3 \pm 0.6$ \\
\hline Öya Formation (Lower) & Higashiōya, Kuchinotsu-machi & $4.8 \pm 0.9$ \\
\hline \multicolumn{3}{|l|}{ Amakusa } \\
\hline Saitsu Formation & Miose, Hondo City & $3.0 \pm 0.3$ \\
\hline \multicolumn{3}{|c|}{ Mogi Plant Fossil Bed (Nagasaki Prefecture) ${ }^{* *}$} \\
\hline \multicolumn{3}{|l|}{ Mitoyo Group (Kagawa Prefecture) } \\
\hline $\begin{array}{l}\text { Yamamoto Formation } \\
\text { (Lowermost) }\end{array}$ & $\begin{array}{l}\text { Iruhi, Saida-machi, } \\
\text { Mitoyo-gun }\end{array}$ & $2.0 \pm 0.5$ \\
\hline \multicolumn{3}{|l|}{ Osaka Group (Hyogo Prefecture) } \\
\hline Awaji Formation & $\begin{array}{l}\text { Kenjō-ga-oka, } \\
\text { Ichinomiya-machi }\end{array}$ & $3.6 \pm 0.3$ \\
\hline \multicolumn{3}{|l|}{ Kobiwako Group (Mie Prefecture) } \\
\hline Iga-Aburahi Formation & $\begin{array}{l}\text { Hattorigawa, Ōyamada-mura, } \\
\text { Ayama-gun }\end{array}$ & $4.6 \pm 0.9$ \\
\hline
\end{tabular}

* Age was determined by Kyoto Fission Track Co., Ltd. ** Nathorst (1883), Florin (1920), Yabe and Endo (1930).

In Lake Biwa, we can find many endemic species of animals and plants. This is natural in the third oldest lake in the world but what is peculiar is the fact that molluses and fishes are similar to the Asian continental fauna (Horie 1961). If these faunas were actually derived, we must study how they migrated from the Asian Continent, particularly from China to the Lake Biwa area. The land connection problems had already been discussed by Yabe $(1929 \mathrm{a}, \mathrm{b})$ on the basis of the geological evidence. Regarding the discovery of mammal fauna in the Ryūkyū Islands, Otuka (1941a, b) conjectured that in that geological age, the East China Sea was the land connected directly to China. It is certainly possible to regard that the East China Sea had been a plain when glacial eustasy took place in the world-wide scale. Based on such a consideration, the author paid his attention to the history of the Seto Inland Sea coastal region which shows marine and non-marine strata exposed to the land. Without the existence of a fresh-water (river) system between China and the Lake Biwa district, aquatic animal migration was impossible. The author collected fresh-water sediments and its contained tephra in order to estimate the age by fission-track dating (Table I).

Ōita Group : This group performs hill morphology in the southern part of Beppu Bay. It is mainly composed of fresh-water strata with interbedded marine strata in the upper part. Its age is regarded as Plio-Pleistocene on the basis of the plant fossils and Stegodon orientalis fossils which were found.

Yame Group : Yame Group distributes around Kuroki and Kurume, southern part of Fukuoka Pref. It is fluvial or lacustrine strata. Kuroki Formation 


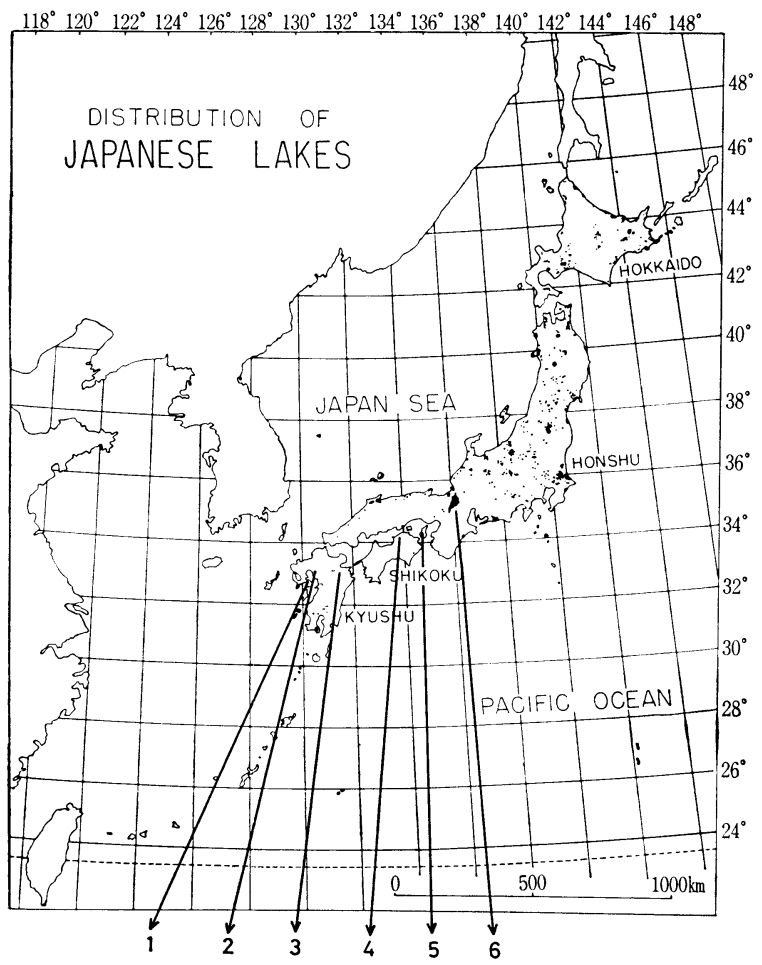

Fig. 1. Age of freshwater sediments in circum Seto Inland Sea. 1a: Kuchinotsu Group (Shimabara), 2.0-4.8 Ma. 1b: Kuchinotsu Group (Amakusa), 3.0 Ma. 1c: Mogi Plant Fossil Bed, 5.6 Ma. 2: Yame Group, 2.7-3.4 Ma. 3: Ōita Group, 0.6-2.9 Ma. 4: Mitoyo Group, 2.0 Ma. 5: Ōsaka Group (Awaji Island), 3.6 Ma. 6: Kobiwako Group (Iga Basin), 4.6 Ma. Ma: Million years.

is distributed around Kuroki (Urata 1957). It is composed of breccia, pumiceous tuff, mudstone and lignite containing a great deal of plant fossils and gravels. Also Stegodon bombifrons fossil was discovered.

Kurume Formation is widely found around Kurume (Urata 1958). It is mainly composed of an alternation of sand, mud, and gravel containing lignite, plant fossils and elephant fossils.

Kuchinotsu Group (Shimabara): This formation is mainly composed of fresh-water strata of the Plio-Pleistocene with interbedded marine strata. Otsuka (1969) divided that group into Oya, Kita Arima, and Minami Kushiyama Formations in an ascending order. It shows an alternation of gravel, sand and silt. It contains a considerable amount of plant fossils. Stegodon cf. insignins and Stegodon akashiensis fossils were also found. Marine strata containing molluscan fossils are interbedded in Kita Arima Formation. Minami Kushiyama Formation is mainly composed of tuff breccia.

Kuchinotsu Group (Hondo) : Fresh-water strata of gravel, sand and silt widely distributed around Hondo, Amakusa. It is called as Saitsu Formation of the Kuchinotsu Group by Otsuka (1970).

Mogi Plant Fossil Bed : This plant fossil bed was firstly investigated by Nathorst (1883) and Florin (1920) and secondly by Yabe and Endo (1930). Its flora is older than the Shiobara Plant Fossil Bed (Yabe and Endo 1930) and shows colder climate than the present one. It is contained in a tuffaceous bed covered by tuffaceous agglomerate and lava. It is regarded as fresh-water sediments deposited 1,000 meters higher altitude location as far as the difference of height is concerned. In other words, it was formed under a colder climate than today's. 
Mitoyo Group : Mitoyo Group is fresh-water sediments of lacustrine-fluviatile origin found in the hill of the western part of Kagawa Prefecture. It is unconsolidated sand, gravel and clay deposits of Plio-Pleistocene strata. It contains Metasequoia flora, Stegodon sugiyamai, and Stegodon akashiensis fossils.

Ōsaka Group (Awaji Formation): It is fresh-water strata composed of sand, gravel and clay distributed in Awaji Island. It is correlated to the Lower Ōsaka Group on the basis of plant fossils of Metasequoia flora and Stegodon akashiensis. It is Plio-Pleistocene in age.

Kobiwako Group (Iga-Aburahi Formation): This formation is distributed in Iga Basin. It is composed of an alternation of sands, clay and gravels. It is earlier stage sediments of the ancient lake of Biwa. Stegodon elephantoides fossil, and plant fossils are found abundantly.

They are the present terrestrial evidence along the Seto Inland Sea, which suggests that older strata are found in both the Lake Biwa region and western Kyūshū. So far as numerals of fission-track age indicate, the existence of a fresh-water channel in the Late Pliocene is thus denoted. However, the age varies by area. This fact suggests that the fresh-water channel in the Seto Inland Sea is composed of a group of independent fresh-water lake basins migrating towards the Lake Biwa basin which is still keeping an ancient lake. Such migration must have been caused by the combination of three geologic features, namely, (1) crustal movements, (2) eustatic sea level fluctuations, and (3) volcanic activity of Aso. Further analysis of these features together with deep drilling of the Seto Inland Sea will answer the land connection problems between the Asiatic Continent and the Lake Biwa district. The present work is just the first step toward solving those difficult problems in Paleobiogeography.

The author devotes his best thanks to Emeritus Prof. Teiichi Kobayashi, M. J. A.. who guided the author in many ways. The author expresses his thanks to Dr. Keiji Takemura who helped him in the field work.

\section{References}

Florin, R. (1920) : Kungl. Svenska Vetenskapsakad. Handl., 61, no. 1, 3-71.

Horie, S. (1961) : Mem. Coll. Sci., Univ. Kyoto, Ser. B, 28, no. 1, 53-71.

Kobayashi, T. (1941) : Jour. Fac. Sci., Imp. Univ. Tokyo, Sec. II, 5, 219-578.

Nathorst, A. G. (1883) : Kungl. Svenska Vetenskapsakad. Handl., 20, no. 2, 3-92.

Otsuka, H. (1969) : Rept. Fac. Sci. Kagoshima Univ. (Earth Sci. Biol.), no. 2, 53-84. — (1970) : Rept. Fac. Sci., Kagoshima Univ. (Earth Sci. \& Biol.), no. 3, 35-65.

Otuka, Y. (1941a): Proc. Imp. Acad., 17, 43-47.

- (1941b) : ibid., 17, 78-82.

(1952): Geotectonics and its Study (Chishitsukōzō to sono Kenkyū). Tokyo,

Hōbundō, 275 pp. (in Japanese).

Tsujimura, T. (1952) : Bull. Geogr. Inst. Tokyo Univ., no. 2, 1-21 (in Japanese).

Urata, H. (1957) : Rept. Earth Sci., Dept. General Educ., Kyushu Univ., 4, 33-43.

- (1958): ibid., 5, 25-37.

Yabe, H. (1929a) : Proc. Imp. Acad., 5, 167-169.

- (1929b) : ibid., 5, 430-433.

Yabe, H., and S. Endo (1930): Jour. Geogr., 42, 599-607 (in Japanese). 